\title{
APPLICATION OF GEOPHYSICAL PROSPECTING METHODS FOR SOIL STRUCTURE CHARACTERIZATION OF THE CATHEDRAL OF SANTO DOMINGO, DOMINICAN REPUBLIC
}

\author{
PÉREZ-CUEVAS. JARUSELSKY ${ }^{*}$, FLORES-SASSO. VIRGINIA ${ }^{1}$, PRIETO- \\ VICIOSO. ESTEBAN ${ }^{2}$, RUIZ-VALERO. LETZAI ${ }^{1}$ AND SANDOVAL. SENÉN ${ }^{3}$ \\ ${ }^{1}$ Pontificia Universidad Católica Madre y Maestra, PUCMM \\ Av. Abraham Lincoln esq. Simón Bolívar \\ Santo Domingo, Distrito Nacional, Dominican Republic \\ e-mail: jaruselskyperez@pucmm.edu.do,www.pucmm.edu.do (*corresponding author) \\ email:\{virginiaflores@pucmm.edu.do, letzairuiz@pucmm.edu.do\} \\ ${ }^{2}$ Universidad Nacional Pedro Henríquez Ureña, UNPHU \\ Av. John F. Kennedy Km 7 1/2 \\ Santo Domingo, Distrito Nacional, Dominican Republic \\ email: \{eprieto@unphu.edu.do\}http://www.unphu.edu.do \\ ${ }^{3}$ Everest Geophysics \\ Cosme Gamella 23, 28270 Colmenarejo Spain \\ email: \{senen@everestgeophysics.com\} https://www.everestgeophysics.com
}

Keywords: Geophysical methods, MASW, H/V spectral ratio, Georadar, Cathedral of Santo Domingo

\begin{abstract}
Hispaniola is in the edge of interaction between the North American and Caribbean plates. In this zone, the occurrence of earthquakes greater than 5.0, MW is frequent, characterizing it as a seismically active zone. These earthquakes cause considerable material damage and can provoke loss of human lives. The Cathedral of Santo Domingo, Primate of the Americas, is in the Colonial City of Santo Domingo. It is the most important colonial building in Dominican Republic, was built between 1521-1541, and is a masonry building made with stone ashlars and covered with stone ribbed vault. However, it is essential to know about the possible seismic behavior that the ground could have in case of a relevant earthquake to try to avoid possible damage to this heritage. For this reason, the aim of this research is to apply geophysical prospecting methods for the seismic site characterization of the Cathedral of Santo Domingo. For this study, the geophysical methods applied were: MASW (Multichannel Analysis of Surface Wave), H/V Spectral Ratio and Georadar. The characterization of site conditions was determined with the values of the average shear wave velocity for the top $30 \mathrm{~m}$ of soil (Vs30) obtained with the MASW method. As a main result it was found that the site seismic class determined with the MASW method was type $C$ very dense soil and soft rock $(360-760 \mathrm{~m} / \mathrm{s})$, according to the NEHRP classification. In addition, the Georadar tests allowed confirming that there are no unknown caverns in the basement of the Cathedral in the first $5 \mathrm{~m}$, thus it is accepted as valid the seismic classification of the soil obtained by the MASW method.
\end{abstract}


Pérez-Cuevas. Jaruselsky, Flores-Sasso. Virginia, Prieto-Vicioso. Esteban, Ruiz-Valero. Letzai and Sandoval. Senén

\section{INTRODUCTION}

Commonly, conventional seismic approaches to near-surface evaluation have been either high-resolution reflection studies or refraction studies dealing with a depth range of a few tens to hundreds of meters. In addition, geophysical surveys are useful tools to characterize the buildings making up the cultural heritage and to monitor the subsoil features on which they are constructed. The information obtained is necessary for planning future restoration work [1]. Therefore, the aim of this research is to apply geophysical prospecting methods for the seismic site characterization of the Cathedral of Santo Domingo.

In 2004, a seismic modeling to simulate a monostatic survey with a single simulation used a ground-penetrating radar (GPR) modeling by using the analogy between acoustic and electromagnetic waves. The exploding-reflector method provides the correct travel times of diffraction and reflection events, whereas the plane-wave method yields more realistic amplitudes and multiple reflections [2]. While in 2007, Barilaro et al, carried out the identification of natural or anthropic buried cavities under the church of St. Sebastiano in Catania, Sicily, Italy, where they used GPR surveys on the pavement of the church and three in situ drillings outside. Through this investigation, the existence of hidden structures was revealed; the results obtained by in situ drillings allowed a detailed characterization of the most superficial layers of the ground [3].

Georadar prospections and three mechanical drillings were carried out in 2008 in a Roman

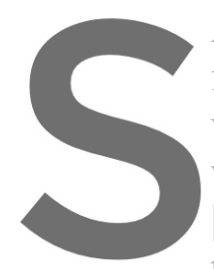
Amphitheatre of Catanis features of the foundatior voids, buried crypts and which allows to retrieve [4]. In 2016, Leucci et a the surface three-dimensional ia, Sicily, Italy, by Caste
tion subsoil of the Amper heterogeneities.
othernation on subsoil
1., carried out a case study
nsional (3D) GPR tech Necropolis in Lecce, south Italy, characterized by different types of graves (pits dug in the

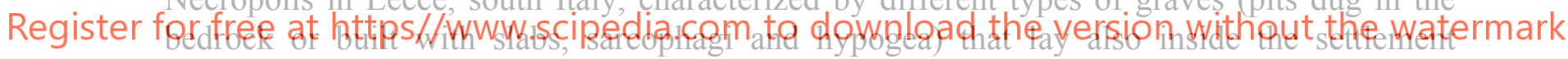
surrounded by city walls [5].

An integrated geophysical survey was carried out in 2018, to confirm the potential occurrence of archaeological remains of the Roman temple dedicated to the Emperor Augustus, at the Tarragona's Cathedral in Spain. The project included electrical resistivity tomography (ERT) and GPR [6]. Also, in 2018, Di Giacomo et al., studied the Medieval cave village of Casalrotto, Mottola, Apulia, Italy [7].

In 2019, Sabrina et al., carried out geophysical surveys for the dynamic characterization of a cultural heritage building and its subsoil: The S. Michele Arcangelo Church, Acireale, eastern Sicily, Italy [1]. These authors argued that the extensive use of geophysical techniques in the last decades, especially for surveys on the cultural heritage, is linked to their low or zero invasiveness, compared to other survey techniques.

On the other hand, the Multichannel Analysis of Surface Waves (MASW) technique was introduced in the late 1990's by the Kansas Geological Survey [8]. The method exploits proven multichannel recording and processing techniques that are similar to those used in conventional seismic reflection surveys. The MASW technique deals with surface waves in the lower frequencies (e.g., 1-30 Hz) and uses a much shallower depth range of research (e.g., a few to a 
Pérez-Cuevas. Jaruselsky, Flores-Sasso. Virginia, Prieto-Vicioso. Esteban, Ruiz-Valero. Letzai and Sandoval. Senén

few tens of meters). The main advantage of MASW is its ability to take into full account the complicated nature of seismic waves that always contain noise waves, such as unwanted higher modes of surface waves, body waves, scattered waves, traffic waves, etc., as well as fundamental-mode surface waves [8].

Anukwu et al., used the MASW method to identify the cause of fractures/cracks observed on the walls and ceilings of a heritage building located in Georgetown, Malaysia. The S-wave velocity revealed that the site is composed of materials with a low shear wave velocity which varies across the site and with depth, thus determining a phenomenon that might be the possible cause of the observed fractures/cracks on the building [9].

In 2013, Tarque et al., carried out a soil seismic profile below the San Felice Martire church, at Poggio Picenze (L'Aquila area, Abruzzo, Central Italy). They studied field geologic observations and drilling and geophysical tests retrieved from previous investigation campaigns. These authors said that the dynamic soil properties were obtained by literature and by the test results. Amplification effects at the site under investigation have been estimated using fully 1D stochastic site response analyses and for the object motion seven (7) real records compatible to the Italian code-based spectrum referred to 475-year return period [10].

Cercato et al., in 2019, applied several geophysical techniques (ambient noise recordings, surface wave methods, electrical resistivity tomography and seismic downhole) to assess the geometry and the low-strain stiffness properties of the different geological units and to provide continuous subsurface imaging throughout the hill of Civita di Bagnoregio (Viterbo, Central Italy). The authors complemented the research with borehole seismic and geotechnican laboratory testing to $p$ were used for investig

2 CATHEDRAL OF SANTO DOMINGO

The Cathedral of Santo Domingo is the most important colonial building of the Dominican Republic. It is the first cathedral in the new world (built between 1521 and 1540). Its

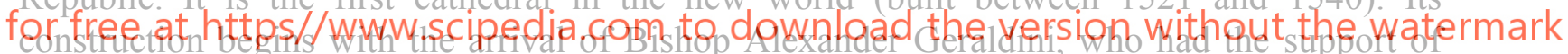

King Charles V. The church is oriented east-west, with the entrance to the west and the altar and polygonal Apse to the east. In the Cathedral the space is based on a canonical study of proportions. It has the ratio of 1:2 (Double Square), where the length of the church is almost double the width and it is adjusted to the golden proportion, characteristic of the late Gothic [12]. The geometrical-proportional layout of the plant and elevations of the church is based on mathematical relationships established on the golden ratio. The height from the floor to the keystone of the central nave is identical to the width of the central nave plus the side nave, giving the golden ratio.

The Cathedral is a saloon plant, with three naves, seven sections with an octagonal presbytery with five faces, fourteen chapels between buttresses and a sacristy on the south side. The floor plan is almost a perfect rectangle that has $45.80 \mathrm{~m}$ long by $23.40 \mathrm{~m}$ wide, covered with Gothic ribbed vaults and tercelets. The vaults are supported by circular pillars and columns. The church is made of coralline and marly limestone blocks. From the bottom of the presbytery to the entrance it is $54.60 \mathrm{~m}$ long. The central nave is $9.63 \mathrm{~m}$ wide from column to column and the lateral naves are $4.80 \mathrm{~m}$ each.

The Cathedral is delimited by to the north, the Colón Park. To the south, the Plaza of the 
Pérez-Cuevas. Jaruselsky, Flores-Sasso. Virginia, Prieto-Vicioso. Esteban, Ruiz-Valero. Letzai and Sandoval. Senén

Priests and the Caribbean Sea. To the east, the Ozama river and to the west the main entrance of the Cathedral (Fig.1).

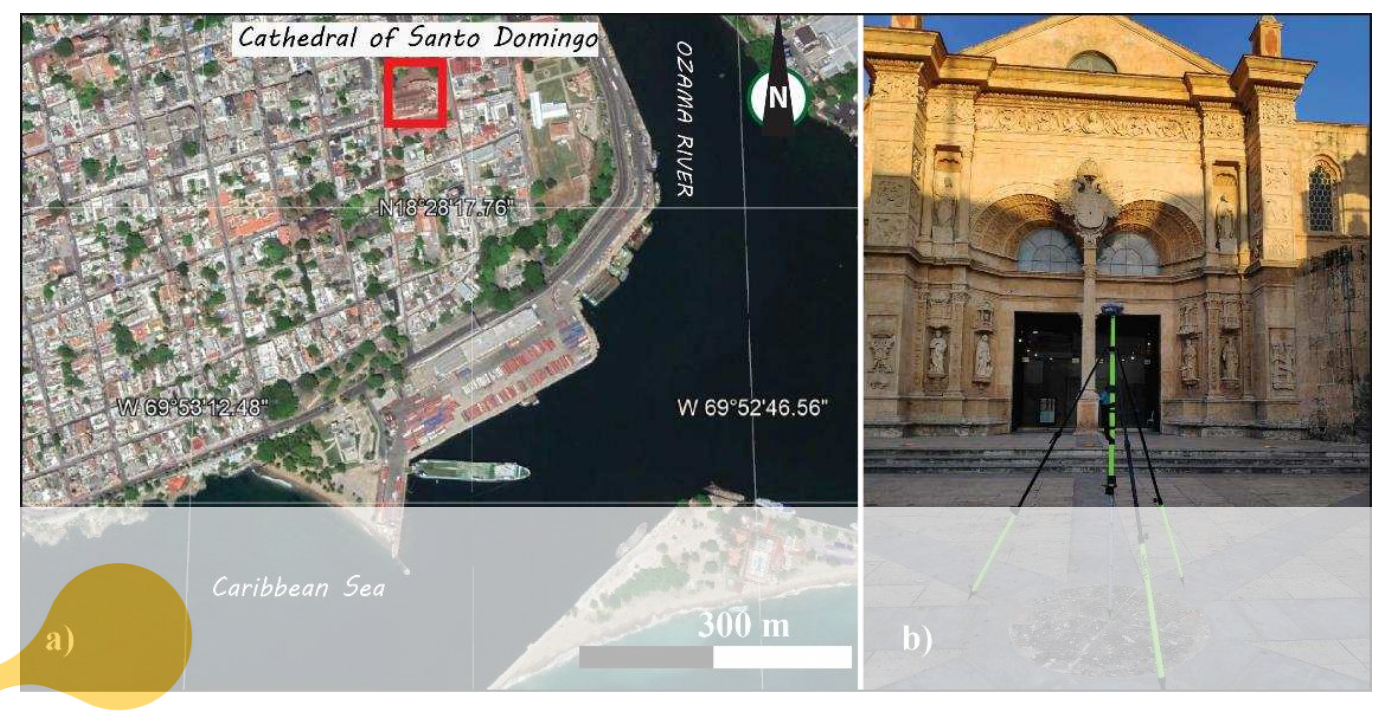

Figure 1: a) Location of the Cathedral of Santo Domingo; b) Photo of the entrance of the Cathedral of Santo Domingo

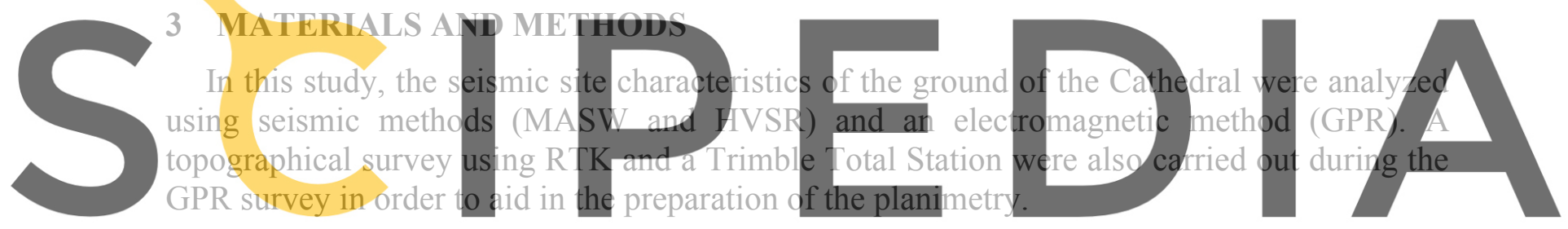

Register for free at https $/ 9$ www.scipedia.com to download the version without the watermark Park et al., describe the MASW method as follows: the Rayleigh wave fundamental mode

dispersion curve is extracted from a shot record. If present, higher modes can also be used and finally the extracted dispersion curves are inverted to generate a 1D shear-velocity model [13]. The shear wave velocity (Vs) depends on the geotechnical parameters of the terrain such as the shear module $(G)$ and the density $(\rho)$ according to equation 1 :

$$
V s=\left[\frac{G}{\rho}\right]^{\frac{1}{2}}
$$

The MASW method was chosen due to the ability to analyze the fundamental and higher modes simultaneously [14]; this advantage enabled us to obtain more accurate shear-wave velocity models. The recording array was composed of 23 vertical component geophones with a geophone spacing of 2 meters (Fig. 2). The separation between the source impact point and first geophone (offset) was $4 \mathrm{~m}$ to minimize near-source effects. The data recording system was a 24-channel "DOREMI" manufactured by Sara Instruments in Italy. 
Pérez-Cuevas. Jaruselsky, Flores-Sasso. Virginia, Prieto-Vicioso. Esteban, Ruiz-Valero. Letzai and Sandoval. Senén

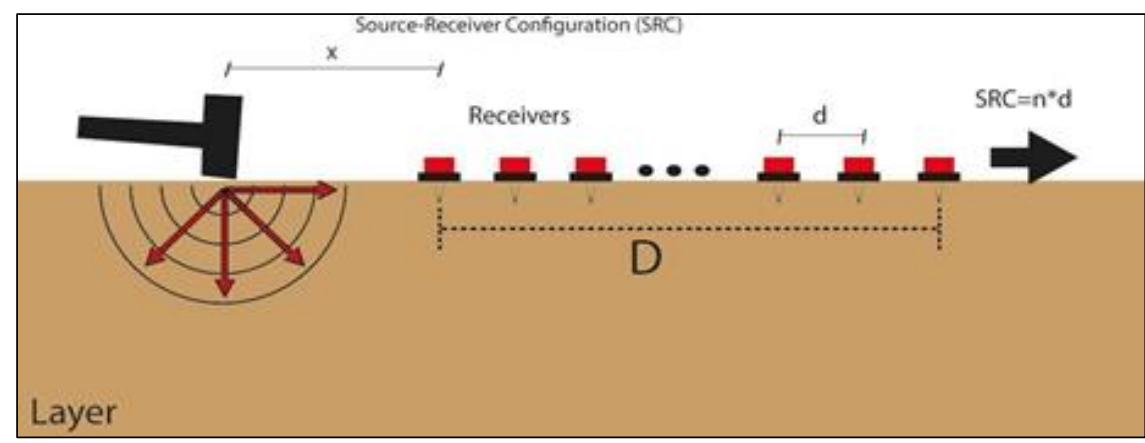

Figure 2: A schematic showing field configuration of instruments used during a seismic survey

The data analysis was carried out with "SurfSeis", software developed by Kansas Geological Survey (KGS), USA [13]. As a source to generate the Rayleigh waves was needed to derive the Vs models, we used a 20 lb. hammer.

Data processing consisted basically in geometry edition, data filtering, muting (if needed), generation of overtones (frequency-time energy diagrams), and finally fundamental and higher mode (when they appeared) identification. Once dispersion curves were determined, they were subjected individually to a mathematical inversion process to obtain a 2D-Vs profile

Four longitudinal profiles were performed for data collection (Fig. 3). A profile in the north of the Cathedral (Line No.1) with a length of 44.25 m, specifically close to Colon Park. The geophones were arranged at $2 \mathrm{~m}$ between them and $4 \mathrm{~m}$ from the source. Two longitudinal profiles in the eastern part of the study site, (Lines No. 2 and No. B) theso w th a long the $\mathrm{m}$ and $33.70 \mathrm{~m}$ respectively. For Line No. 2, 12 geophones were used and the between them was $1 \mathrm{~m}$; Line No. 3 consisted of 15 geophones separated at completion of these, three more profiles were calt 4), in the South, with a length of $70 \mathrm{~m}$, using 23 geophones at $2 \mathrm{~m}$ between them and $4 \mathrm{~m}$ from

Register for free at https//www.scipedia.com to download the version without the watermark

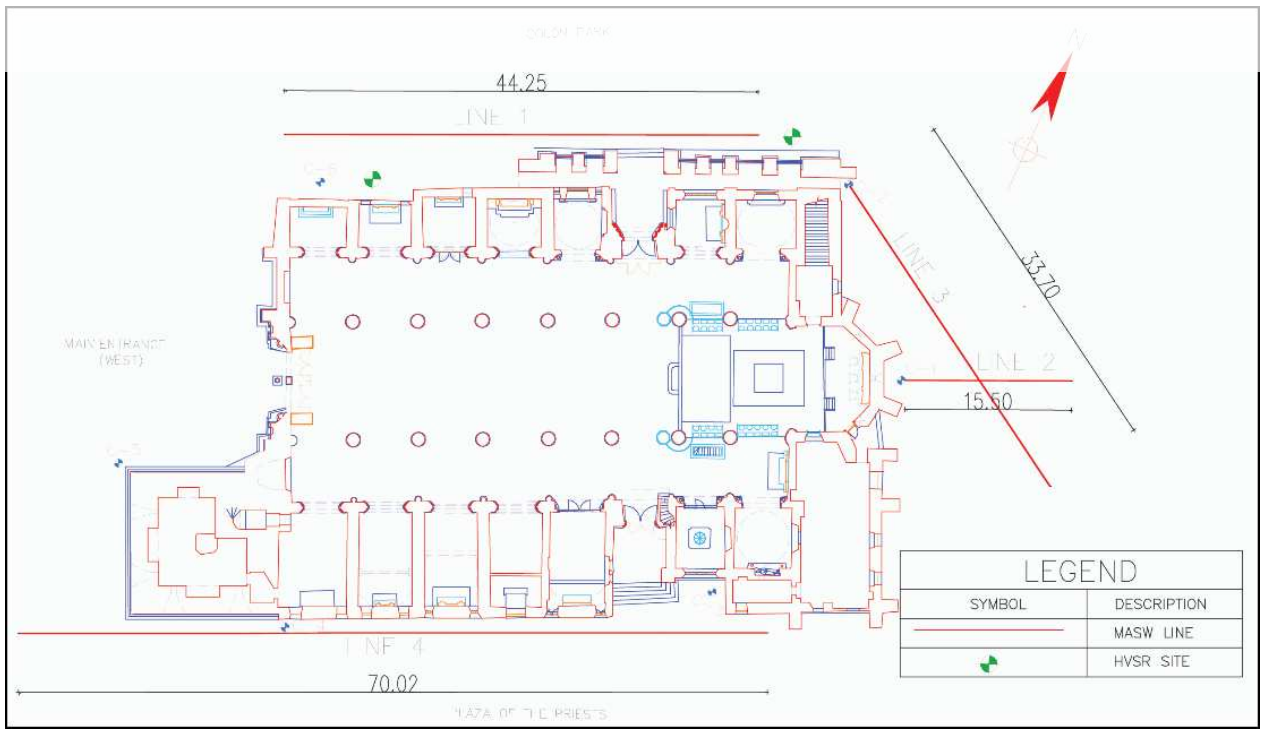

Figure 3: Location of the MASW and HVSR profiles made in the Cathedral 
Pérez-Cuevas. Jaruselsky, Flores-Sasso. Virginia, Prieto-Vicioso. Esteban, Ruiz-Valero. Letzai and Sandoval. Senén

\section{$3.2 \mathrm{H} / \mathrm{V}$ spectral ratio}

A SARA SS45PACK (integrated $4.5 \mathrm{~Hz}$ sensors) triaxial broadband accelerometer was used for recording the seismic data (environmental seismic noise) (Fig. 4).
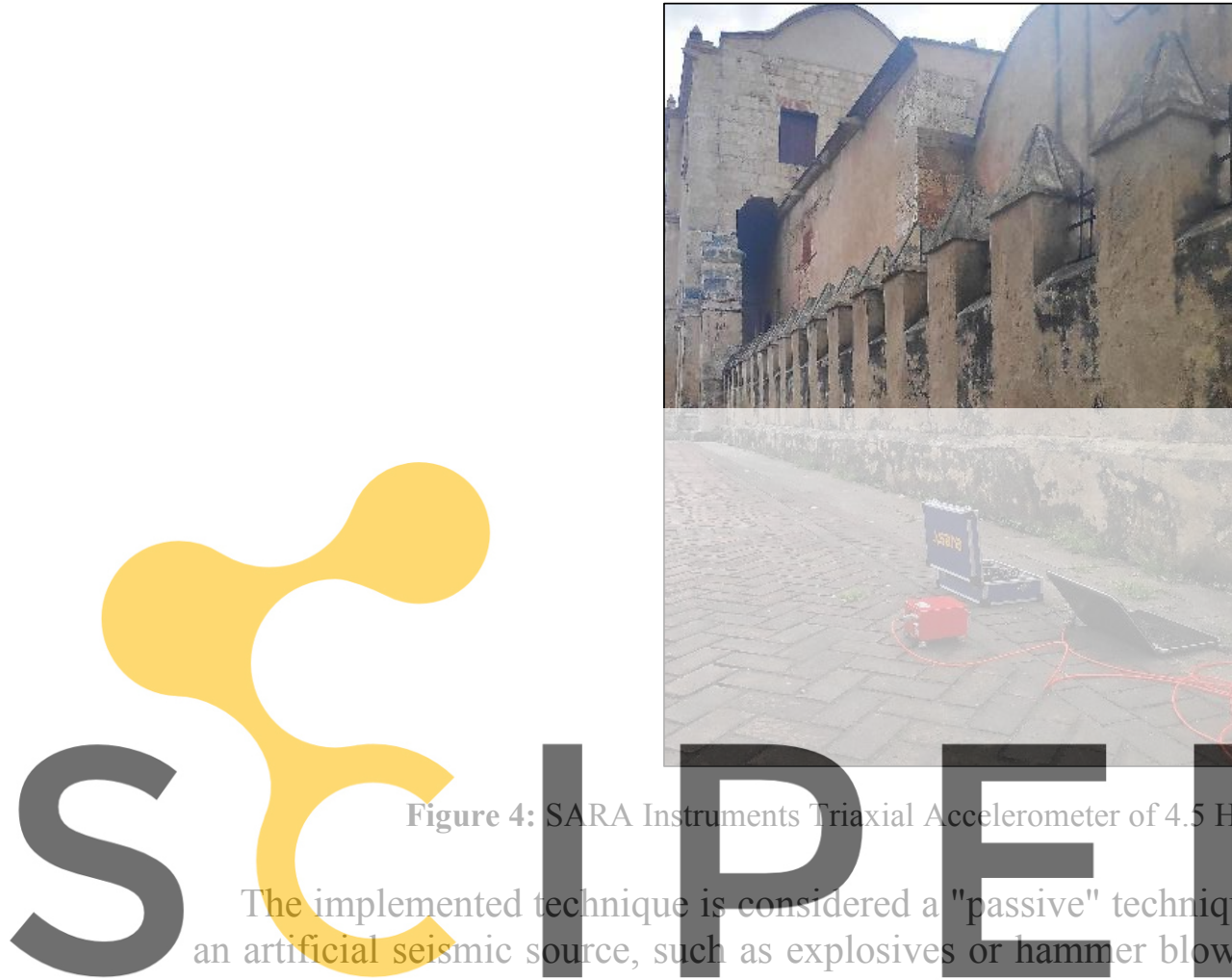

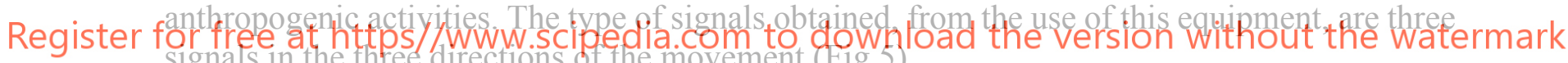
signals in the tifiee arrections or the miovement thig.).

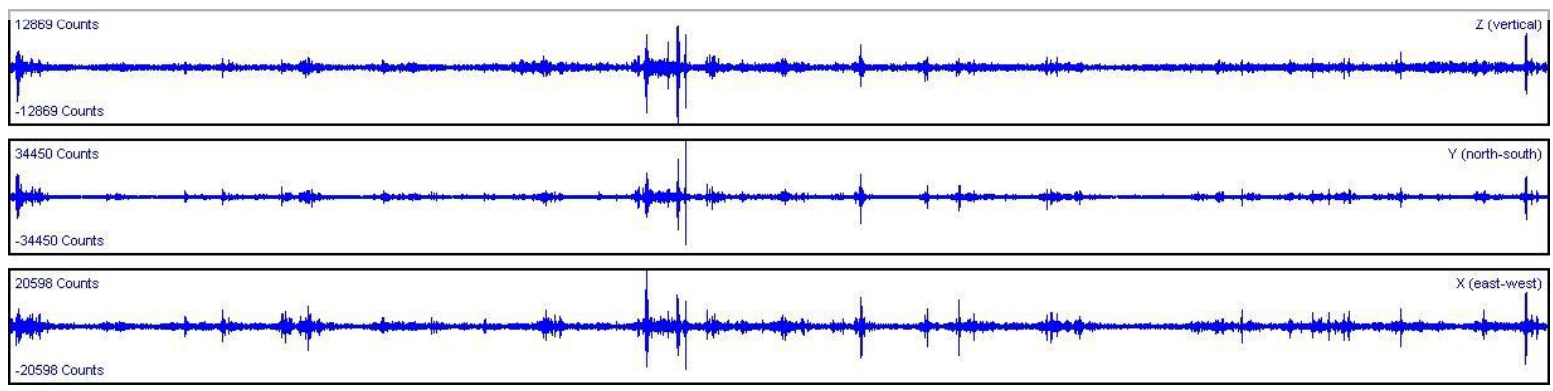

Figure 5: Seismic signals obtained from the triaxial accelerometer

The signals in the plane (Horizontal) are averaged, then the Fourier spectra are obtained and by the application of the Nakamura Modified Transfer Function [15]:

$$
T F_{H W}=\frac{S_{H S}}{S_{V S}}
$$


Pérez-Cuevas. Jaruselsky, Flores-Sasso. Virginia, Prieto-Vicioso. Esteban, Ruiz-Valero. Letzai and Sandoval. Senén

\subsection{Georadar}

The Georadar survey is an advanced geophysical technique that uses short pulses of highfrequency electromagnetic waves into the subsurface and analyzes the reflected waves [16].

The field of general applications of the Georadar is very wide, being used in construction projects, audits, site evaluations, environmental impact studies and geological and archaeological studies. In cultural heritage sites as the study area, the GPR is most useful in mapping the dimensions of crypts and ground structures.

The GPR survey (Fig. 6) was carried out using a Georadar device equipped with a $500 \mathrm{MHz}$ antenna (Model DX2125 by 3D-Radar) to obtain adequate resolutions up to an investigation depth of $5 \mathrm{~m}$.
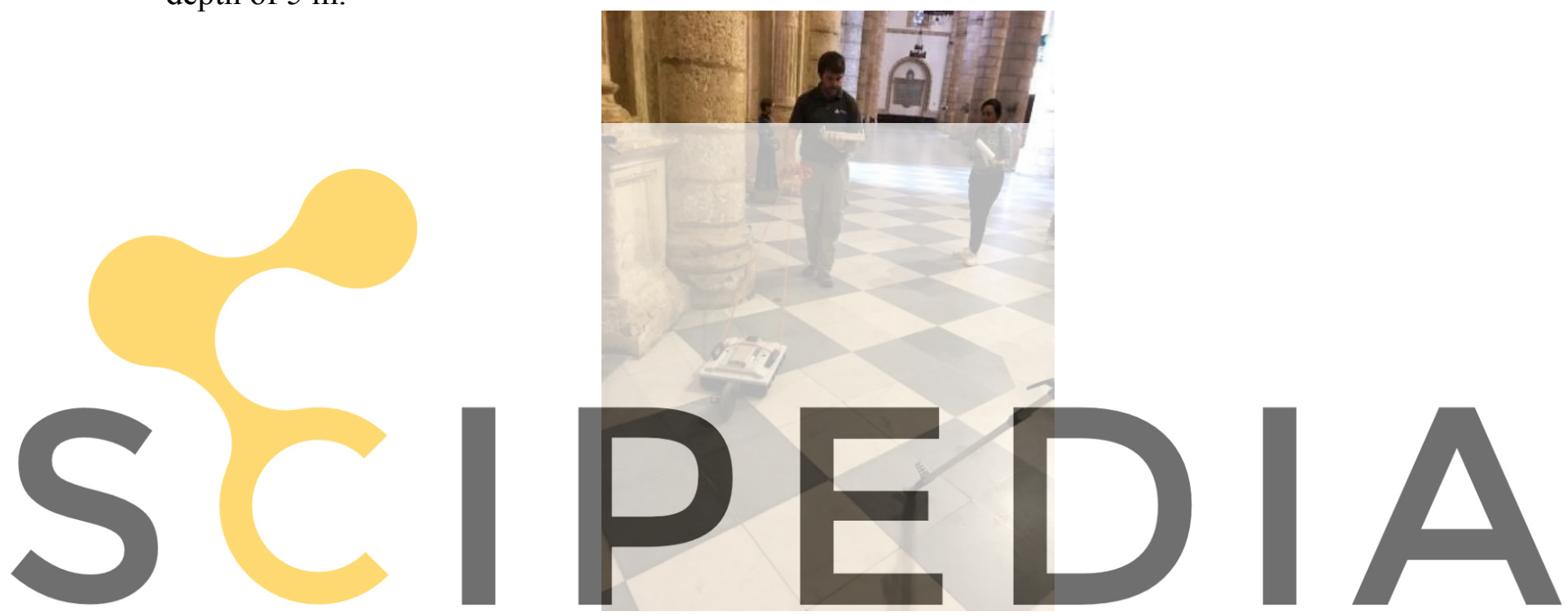

\section{Register for free at https//www.scipedia.com to download the version without the watermark}

The data acquisition phase was done by making lines and meshes (Fig.7). Inside the cathedral, 17 lines were made in the longitudinal direction, distributed as follows: 3 in the central span of the altar and 7 in the extreme span.

In each span, the lines were approximately $0.58 \mathrm{~m}$ apart. After data collection in the openings, data was taken in the chapels and the sacristy where a total of 47 lines were made, considering that the study area has 14 chapels.

Within the collection of data inside the area of interest, the study was continued in the crypt of the Trascoro, where a total of 12 lines were made, both horizontally and vertically, to check if this crypt housed some burial.

After the data collection inside the building, lines were carried out outside, specifically in the garden east of the study area, the Plaza of the Priests, the main entrance to the West and the corridors in the North part; having a total of 39 lines in these zones. 
Pérez-Cuevas. Jaruselsky, Flores-Sasso. Virginia, Prieto-Vicioso. Esteban, Ruiz-Valero. Letzai and Sandoval. Senén

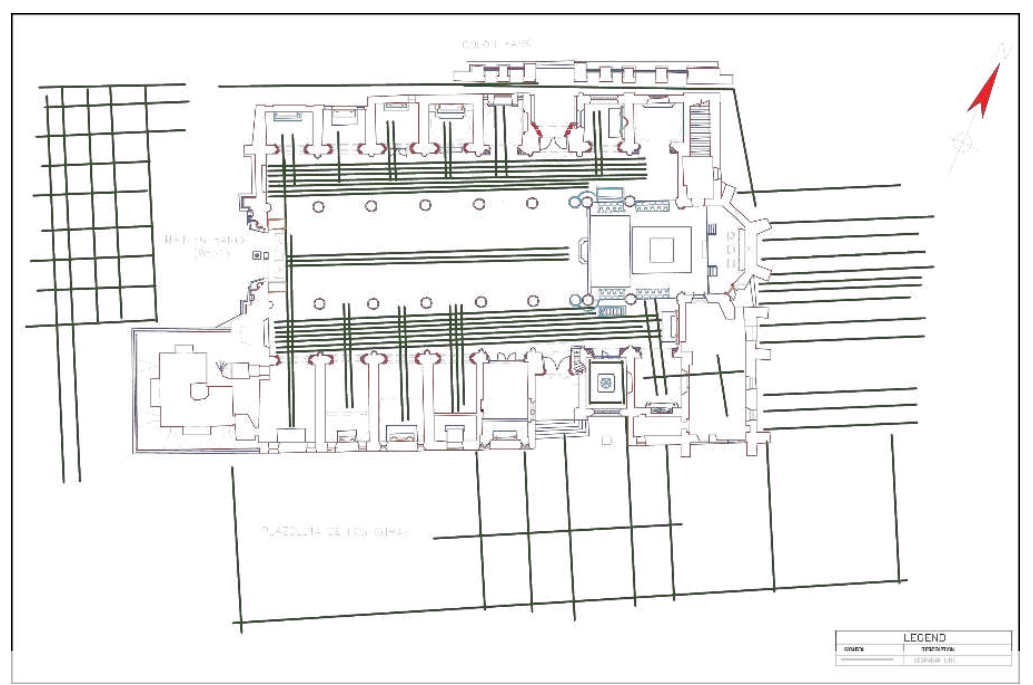

Figure 7: Plan view of the GPR lines made throughout the Cathedral

\section{RESULTS AND DISCUSSIONS}

\subsection{Seismic Methods}

Figure 8 shows the shear-wave velocity model of Line No. 4, which is labelled

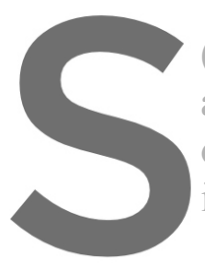
(Fig. 3), obtained from and shows Vs values be of $30 \mathrm{~m}$. From this Vs model is 70 meters long.
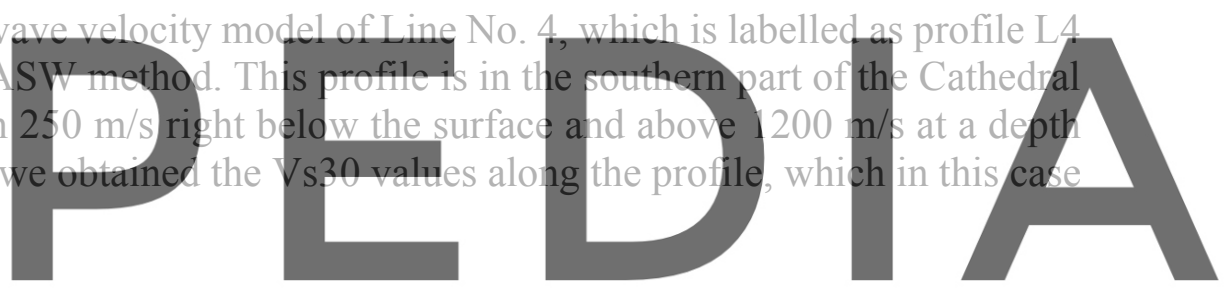

Register for free at https//www.scipedia.com to download the version without the watermark

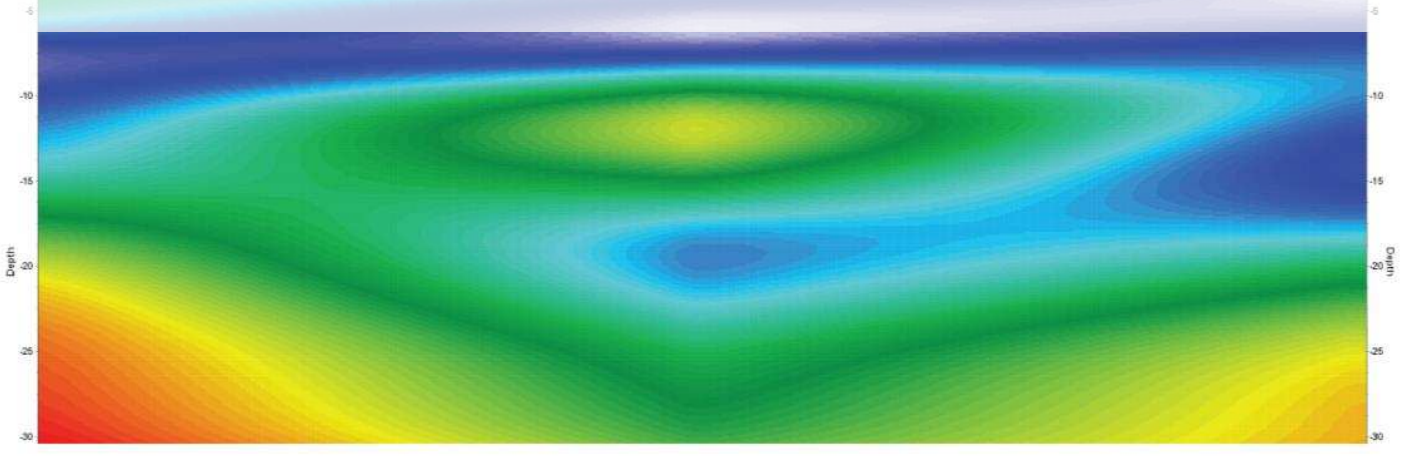

Figure 8: 2-D shear-wave velocity section from the MASW survey conducted in the southern part of the Cathedral

As it can be noted in Fig. 9, the range of Vs30 values obtained from the MASW method is between $530 \mathrm{~m} / \mathrm{s}$ and $738 \mathrm{~m} / \mathrm{s}$, thereby qualifying the soils of that area as NEHRP class C-type. 
Pérez-Cuevas. Jaruselsky, Flores-Sasso. Virginia, Prieto-Vicioso. Esteban, Ruiz-Valero. Letzai and Sandoval. Senén

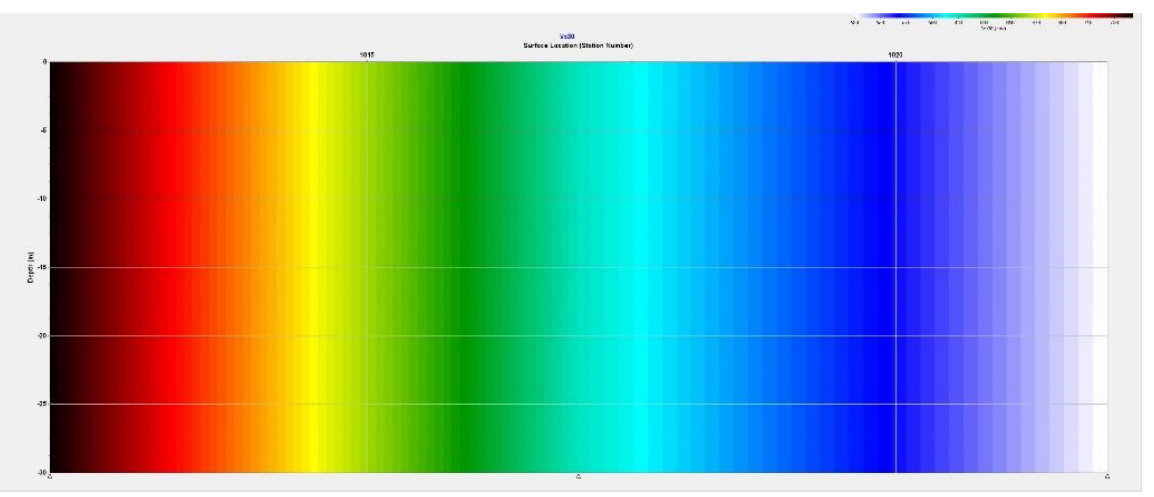

Figure 9: Vs30 MASW profile obtained in the Plaza of the Priests located in the southern part of the Cathedral

On the other hand, the results obtained by measuring the accelerations of the soil for each of the points defined above in Figure 3 are shown. After applying the filters and the smoothing proposed by Konno-Ohmachi [17], the value for the fundamental frequency of the North part of the Cathedral obtained was $0.682 \mathrm{~Hz}$ (Fig. 10).
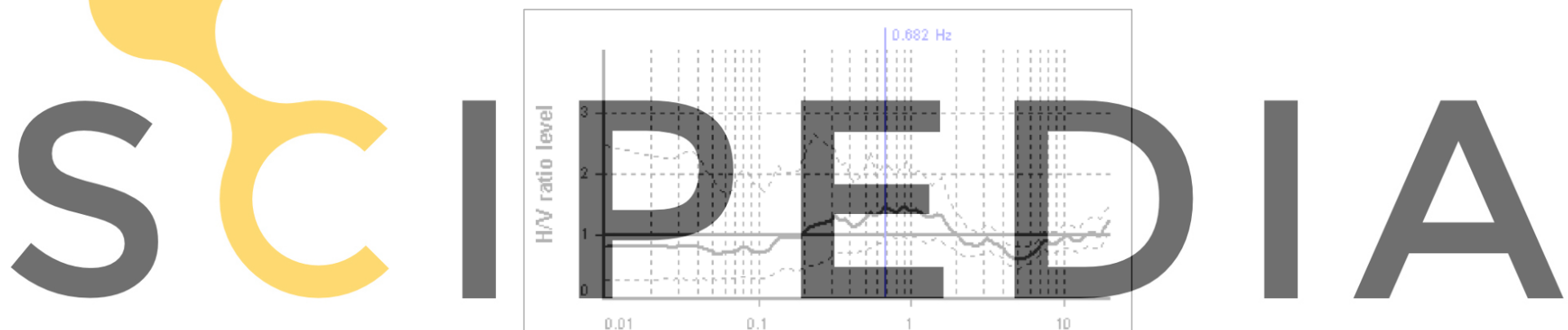

Register for free at https//www.scipedia.com to dowuency [Hiz] Figure 10: Fundamental frequency of the soil based on the SESAME criteria

\subsection{Georadar Survey}

In general, no previously unknown caverns or other cavities were found in the first $5 \mathrm{~m}$ of soil. The GPR003 radargram (Fig. 11) shows some vertical anomalies, but these pass through the crypt of the Trascoro and a tombstone located in the center of the aisle of the altar, which are already mapped. Therefore, the classification of the soil surface structure obtained by the MASW method is accepted as valid.

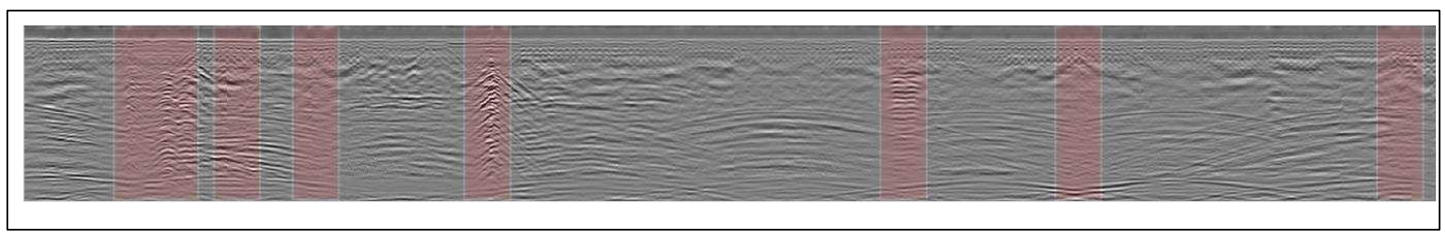

Figure 11: Radargram of a longitudinal E-W line that passes through the center vane of the cathedral. 
Pérez-Cuevas. Jaruselsky, Flores-Sasso. Virginia, Prieto-Vicioso. Esteban, Ruiz-Valero. Letzai and Sandoval. Senén

Another detail that can be observed in radargrams is the presence of parabolas. These parabolas are the product of the influence exerted by lamps located at $5 \mathrm{~m}$ above ground level, in addition to the reflection of the electromagnetic wave at the end of the line. This makes it clear that the test is delicate, and that special care must be taken during the processing to correctly interpret the results.

\section{CONCLUSIONS}

- $\quad$ The GPR surveys confirmed that there are no unknown caverns or other cavities in the subsoil of the Cathedral in the first $5 \mathrm{~m}$, so the classification of the surface structure of the soil obtained by the MASW method is accepted as valid.

- $\quad$ The Vs30 values obtained with the MASW test showed a variation that coincides with the topography of the land. The highest values of Vs30 were obtained in profile 3 and 4 , which were tested in the lower part of the Cathedral, that is, in the southern part closest to the sea.

The frequency determined by the HVSR method further confirms the site class obtained with the MASW survey.

The site class determined with the Vs30 results found in this investigation for all models was type C (360-760 m/s), according to NEHRP soil seismic classification.

The results of this study are consistent with other soil studies conducted in the area. The values of Vs30 in the first 3 to 4 meters of each model correspond to rigid clay

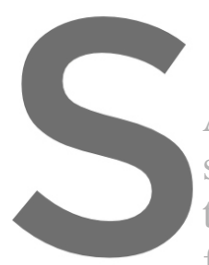
and sandy solls

Acknowledgements.

structure behavior of

tests. Case: Primate

funded by FONDOCy
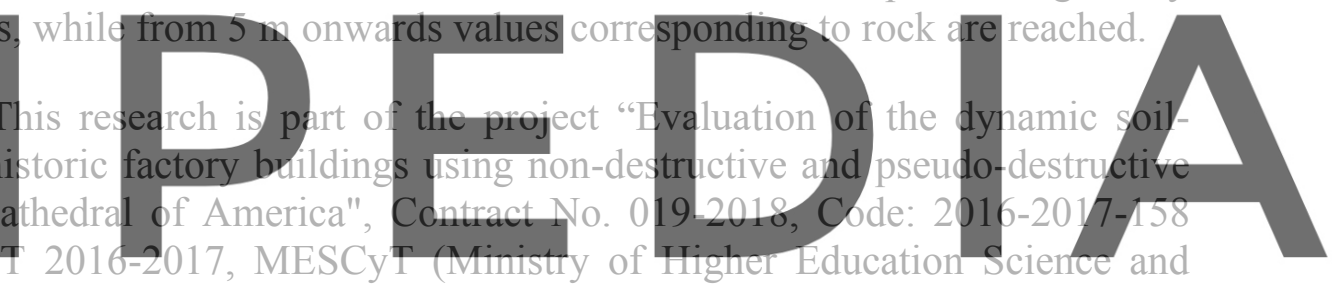

Technology). The authors also thanks Oficina de la Obra y Museos de la Catedral de Santo

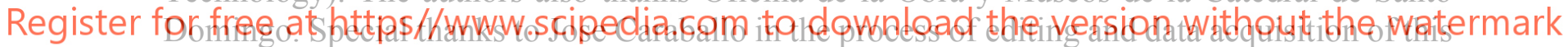
research.

\section{REFERENCES}

[1] Sabrina, G., Sebastiano, I., Graziano, P., Domenico, B., Giuseppe, L. and Francesco, P. Geophysical surveys for the dynamic characterization of a cultural heritage building and its subsoil: The S. Michele Arcangelo Church (Acireale, eastern Sicily). Journal of Cultural Heritage, 36 (2019) 72-84. https://doi.org/10.1016/j.culher.2018.09.015

[2] Baradello, L., Carcione, J.M. and Gei, D. Fast monostatic GPR modeling. Geophysics. 69 (2004), pp.466-471. Doi: 10.1190/1.1707066.

[3] Barilaro, D., Branca, C., Gresta, S., Imposa, S., Leone, A. and Majolino, D. Ground penetrating radar (G.P.R.) surveys applied to the research of crypts in San Sebastiano's church in Catania (Sicily). Journal of Cultural Heritage. 8, 73-76. doi:10.1016/j.culher.2006.10.003

[4] Castellaro, S., Imposa, S., Barone, F., Chiavetta. F., Gresta. S. and Mulargia, F. Georadar and passive seismic survey in the Roman Amphitheatre of Catania (Sicily). Journal of Cultural Heritage, 9 (2008) 357-366. doi:10.1016/j.culher.2008.03.004 
[5] Leucci, G., De Giorgi, L., Di Giacomo, G., Ditaranto, I., Miccoli, I. and Scardozzi, G. 3D GPR survey for the archaeological characterization of the ancient Messapian necropolis in Lecce, South Italy, Journal of Archaeological Science: Reports, Reports 7 (2016) 290-302. http://dx.doi.org/10.1016/j.jasrep.2016.05.027

[6] Casas, A., Cosentino, P. L., Fiandaca, G., Himi, M., Macias Solé, J.M., Martorana, R., Muñoz, A., Rivero Rivero, L., Sala, R. and Teixell, I. Non-invasive Geophysical Surveys in Search of the Roman Temple of Augustus Under the Cathedral of Tarragona (Catalonia, Spain): A Case Study, Surveys in Geophysics, April 2018. doi.org/10.1007/s10712-0189470-6

[7] Di Giacomo, G., De Giorgi, L., Ditaranto, I., Leucci, G., Miccoli, I. and Scardozzi, G. The Medieval cave village of Casalrotto (Mottola, Apulia): New data on the settlement and its necropolis from archaeological and geophysical measurements, Measurement, 128 (2018) 96-103. https://doi.org/10.1016/j.measurement.2018.06.038

[8] Park, C.B., Miller, R.D., Xia, J. and Ivanov, J. Multichannel analysis of surface waves (MASW) active and passive methods", in Kansas Geological Survey, Lawrence, USA, January 2007.

[9] Anukwu, G.C., Khalil, A.E., Nawawi, M., Abdullah, K. and Abdullah, F.M. Multi-channel analysis of surface waves (MASW) using CMP analysis to identify soil problems threat on the heritage site at Georgetown, Malaysia, International Geophysical Conference, Beijing, China, 24-27 April 2018. doi.org/10.1190/IGC2018-404

[10] Tarque, N., Lai, C.G., Bozzoni, F., Miccadei, E., Piacentini, T., Camata, G. and Spacone, E. Expected ground motion at the historical site of Poggio Picenze, Central Italy, with reference to current Italian building code, Engineering Geology, 166 (2013) 100-115. http://dx.doi.org/10.1016/j.enggeo.2013.09.003.

[11] Cercato, M., De Donno, G., di Giulio, A., Lanzo, G. y Tommasi, P. Dynamic Characterization of the hill of Civita di Bagnoregio (Viterbo, Central Italy) for seismic response analysis. Engineering Geology (2019), https://doi.org/10.1016/j.enggeo.2019.105463

[12] Flores Sasso, V. and Prieto Vicioso, E. El modelo Hallemkirche o iglesia salón en el reino de Castilla de Ultramar. La Catedral de Santo Domingo, in "Obra Congrua, 1416. 500 aniversario de la Consulta de la Catedral de Girona, Universidad de Girona, Departamento de Arquitectura e Ingeniería de la Construcción, Colegio de Aparejadores, Arquitectos Técnicos e Ingenieros de la Edificación de Girona. 2017. pp. 183-1992.

[13] Park, C. B., Miller, R. D., and Xia, J. (1999). Multichannel analysis of surface waves. Geophysics, 64, 800-808.

[14] Xia, J., Park, C. B., Hunter, J. A., Harris, J. B., and Ivanov, J. (2002). Comparing shearvelocity profiles from multichannel analysis of surface wave with borehole measurement. Soild Dynamics and Earthquake Engineering (SDEE), 22(3), 181-190.

[15] Nakamura, Y. (1989). A method for dynamic characteristics estimation of subsurface using microtremors on the ground surface. Quarterly Report of Railway Technical Research Institute (RTRI): 3, 25-33. 
Pérez-Cuevas. Jaruselsky, Flores-Sasso. Virginia, Prieto-Vicioso. Esteban, Ruiz-Valero. Letzai and Sandoval.

Senén

[16] Byeong-Jin P., Jeongguk K., Jaesun L., Man-Sung K. and Yun-Kyu A. Underground Object Classification for Urban Roads Using Instantaneous Phase Analysis of GroundPenetrating Radar (GPR) Data. Remote Sensing 10(9): 1417 (2018)

[17] Konno, K., and Ohmachi, T. (1998). "Ground-motion characteristic estimated from Spectral Radio between Horizontal and Vertical Components of Microtremors". Bulletin of the Seismological Society of America: 88, 228-241. 